\title{
ИСТОРИЯ ВОЗНИКНОВЕНИЯ И ДЕЯТЕЛЬНОСТЬ НЕКАНОНИЧЕСКОЙ «ХРИСТИАНСКОЙ ИСТИННО-ПРАВОСЛАВНОЙ ЦЕРКВИ» СЕРАФИМА (МЕДВЕДЕВА)
}

\author{
Бочков Павел Владимирович \\ доктор богословия, доктор теологии, к.ю.н., профессор кафедры \\ Межрегиональная Академия Управления персоналом, г. Киев, Украина
}

Аннотация: В статье кратко рассматривается история малочисленной неканонической православной юрисдикции - «Христианской ИстинноПравославной Церкви», осуществляющей свою деятельность на территории Украины и возглавляемой бывшим архимандритом Серафимом (Медведевым). Выступая в качестве духовного руководителя, бывший священнослужитель, находясь в состоянии раскола с канонической Православной Церковью, пришел к ряду выводов, несовместимых с Православным вероучением, что, в свою очередь, привело к вырождению его небольшой общины в околоправославную секту.

Ключевые слова: Серафим (Медведев), неканонические юрисдикции, церковный раскол, греческие старостильники.

\section{THE HISTORY OF ESTABLISHMENT AND ACTIVITIES OF THE NON-CANONIC "CHRISTIAN TRUE-ORTHODOX CHURCH" SERAFIM (MEDVEDEV)}

\section{Bochkov Pavel Vladimirovich}

\begin{abstract}
The article briefly examines the history of a small non-canonical Orthodox jurisdiction - the "Christian True Orthodox Church", which operates on the territory of Ukraine and is headed by the former Archimandrite Seraphim (Medvedev). Acting as a spiritual leader, the former clergyman, being in a state of schism with the canonical Orthodox Church, came to a number of conclusions incompatible with the Orthodox faith, which, in turn, led to the degeneration of his small community into a near-Orthodox sect.
\end{abstract}

Key words: Seraphim (Medvedev), non-canonical jurisdictions, church schism, Greek Old Calendarists. 


\section{НАУКА, ОБЩЕСТВО, КУЛЬТУРА: ПРОБЛЕМЫ И ПЕРСПЕКТИВЫ ВЗАИМОДЕЙСТВИЯ В СОВРЕМЕННОМ МИРЕ}

О данной малочисленной группе в настоящее время известно не много. К началу 2021 года вся ее деятельность свелась к активному присутствию ее лидера - «отца» Серафима (Медведева) - в социальных сетях и тиражирования в них видеозаписей с его рассуждениями по различным вопросам духовной жизни. По некоторым сведениям, стало известно, что ее основатель и единственный клирик Серафим (Медведев) до 1993 г. в качестве иеромонаха находился в юрисдикции Русской Православной Церкви Московского Патриархата. На волне критики церковной иерархии и учреждения на постсоветском пространстве структур Русской Православной Церкви Заграницей (РПЦЗ). Медведев разорвал общение с РПЦ и вошел в юрисдикцию РПЦЗ. Однако, не удовлетворившись этим, иеромонах Серафим (Медведев) уклонился в раскол, войдя в юрисдикцию «Восточно-Европейского Экзархата» ««Каллиникитского» Синода Церкви ИПХ Греции», фактически став клириком греческой старостильной неканонической группы. В ее составе он был возведен в достоинство «архимандрита». При этом он также являлся настоятелем СвятоТроицкого монастыря [14, с. 298].

В феврале 2006 г. «иеромонах» Серафим (Медведев) и его община верующих, проживающая в полузаброшенном хуторе в Роменском районе Сумской области в Украине [8], часть домов которого выкупили последователи Медведева, покинула ««Каллиникитский» Синод Церкви ИПХ Греции» [2, с. 60 - 71]. Вскоре Медведев объявил, что его религиозная группа также является частью Катакомбной церкви, вследствие чего она получила название «Катакомбная Истинно Православная Церковь», породив очередную неканоническую псевдокатакомбную юрисдикцию [4].

Спустя некоторое время, «архимандрит» Серафим (Медведев) разочаровался в идеалах монашества и женился, что стало концом существования Троицкого монастыря. В настоящее время Медведев проповедует, что монашество сейчас невозможно и зачастую вредно, выступает за женатый епископат. За его богослужениями поминаются абстрактные «истинно-православные епископы», т.к. действительные и благодатные православные иерархи общине Медведева не известны. В 2008 году юрисдикция сменила название на нынешнее - «Христианская ИстинноПравославная Церковь» [4]. Сложив с себя монашество, Серафим (Медведев) стал именовать себя «священником» и «духовным руководителем» своей «церкви» [13]. Именно как «отец Серафим» он довольно широко известен в социальных сетях. 


\section{НАУКА, ОБЩЕСТВО, КУЛЬТУРА: ПРОБЛЕМЫ И ПЕРСПЕКТИВЫ ВЗАИМОДЕЙСТВИЯ В СОВРЕМЕННОМ МИРЕ}

В своих религиозных концепциях Серафим (Медведев) в основном сосредоточен на псевдоэсхатологических и апокалиптических идеях, на мысли, что все священнослужители Православной Церкви, кроме него, отпали от истины и уклонились в апостасию, и более не могут вести верующих ко спасению души. Развивая свои идеи в таком русле, бывший архимандрит пришел к выводу, что все церковные каноны и правила в настоящее время бесполезны, так как близится завершение земной истории человечества вследствие Апокалипсиса и грядущего Страшного Суда. Единственным путем ко спасению Медведев считает «правильную борьбу со страстями» и воспитание в себе «правильного духовного чувства». Серафим (Медведев) критически относится и различным церковным движениям. Осуждает имяславцев, последователей религиозно-мистического движения в РПЦ первой половины XX века, за что его, в свою очередь, осуждает бывший клирик РПЦЗ, «иерей» Олег Моленко [5, с. 362], руководитель другой неканонической православной юрисдикции апокалиптического характера - «Вселенской Церкви Иоанна Богослова» [1, с. 209 - 219].

Медведев активно использует социальные сети и интернет-сообщества для проповеди и распространения своих взглядов с целью не только донести до возможно большего числа слушателей свои идеи, но и увеличить число своих последователей. В свою очередь, эта деятельность не раз была подвержена справедливой критике со стороны православных священнослужителей и журналистов, т.к. проповедуемые Медведевым еретические идеи сродни деструктивным сообществам и псевдоправославным сектам [3; 6]. Свою проповедь Медведев ведет на русском языке, и несмотря на то, что проживает и совершает богослужения на территории Украины, не поддерживает идеи автокефалии Украинской Православной Церкви, критикуя все православные юрисдикции, имеющиеся на территории Украины. Серафим (Медведев) призывает своих последователей не ходить на богослужения в православные храмы как в «безблагодатные».

В общине Медведева, позиционирующей себя в качестве полноценной православной юрисдикции - «церкви», активно работает издательство «Параклит», выпускающее богослужебную литературу и различные сборники [7], критикующие каноническое устройство Православной Церкви, Московскую Патриархию [10], ее иерархию и священство [11; 12], а также канонизированных ею святых (например, решительно отвергаются канонизации свт. Луки (ВойноЯсенецкого), св. Матроны Московской, прп. Кукши Одесского и др.) [9] и проч. 


\section{НАУКА, ОБЩЕСТВО, КУЛЬТУРА: ПРОБЛЕМЫ И ПЕРСПЕКТИВЫ ВЗАИМОДЕЙСТВИЯ В СОВРЕМЕННОМ МИРЕ}

Современные власти Российской Федерации и Украины Серафим (Медведев) считает антихристианскими политическими режимами и наследниками гонителей Церкви - коммунистов, ведущими к погибели народы и приближающими приход в мир антихриста. Единственным и бессменным «главой» и «клириком» данной группы с середины 1990-х годов и по настоящее время является бывший «архимандрит» Серафим (Медведев).

Являясь типичной псевдоправославной группой сектантского характера, община Медведева не получила широкого распространения. Она фактически представляет собой крайне малочисленную группу последователей, в основном разобщенных расстояниями, проживающих в разных странах постсоветского пространства и не участвующих с Медведевым в какой-либо совместной богослужебной жизни. Вследствие своей малочисленности и социального изоляционизма, данная группа, являясь печальным фактом уклонения в раскол бывшего клирика, тем не менее не стала серьезной угрозой церковному единству, в наше время и так переживающему нелегкий период.

\section{Список литературы}

1. Бочков Павел, свящ. Обзор неканонических православных юрисдикций XX-XXI вв. Т. 5: Дисциплинарно-психологические расколы: монография. - СПб.: Свое издательство, 2020.

2. Бочков Павел, священник. Обзор неканонических православных юрисдикций XX-XXI вв. Т. 4: Греческий старостильный раскол и производные от него неканонические юрисдикции: монография. - СПб.: Свое издательство, 2018.

3. Возмутительные действия священника Серафима Медведева // КОМПАС - медиаплатформа МирТесен [Электронный ресурс]. - 2020. - Режим доступа: https://rossijane.mirtesen.ru/blog/43148799438/Vozmutitelnyie-deystviyasvyaschennika-Serafima-Medvedeva?nr=1\&utm_referrer=mirtesen.ru\# 42751044665 - Дата доступа: 20.04.2020.

4. Малые группы «альтернативного» православия // Иерархия литургических церквей [Электронный ресурс]. - 2020. - Режим доступа: http://www.hierarchy.religare.ru/h-orthod-malipc.html - Дата доступа: 20.04.2020.

5. Моленко Олег, о[теu]. Вопросы по Священному Писанию. Православие и лжеправославие, серия Православие в вопросах и ответах. Т. 2. - М.: Братство во имя апостола Иоанна Богослова, 2008. 


\section{НАУКА, ОБЩЕСТВО, КУЛЬТУРА: ПРОБЛЕМЫ И ПЕРСПЕКТИВЫ ВЗАИМОДЕЙСТВИЯ В СОВРЕМЕННОМ МИРЕ}

6. Николаева И.В. Христианская Истинно-Православная Церковь // Познание правой веры [Электронный ресурс]. - 2020. - Режим доступа: http://vera-istina.blogspot.com/2010/03/blog-post_05.html - Дата доступа: 20.04.2020.

7. Об адаптации или русификации богослужебного языка. Сборник материалов для размышления. Сост. Серафим (Медведев). Машинопись. - Б.м., б.г.

8. Письмо иеромонаха Ефрема (Болховитова) священнику Павлу Бочкову от 09.09.2010 // Архив автора.

9. Серафим [Медведев], о[теи]. О святых МП // Христианская Церковь [Электронный pecypc]. - 2021. - Режим доступа: https://www.paraklit.org/ fragment20/o-svjatyh-mp - Дата доступа: 20.01.2021.

10. Серафим [Медведев], о[тещ]. О спорах и пути погибели МП // Христианская Церковь [Электронный ресурс]. - 2021. - Режим доступа: https://www.paraklit.org/fragment20/o-sporah-i-puti-pogibeli-mp - Дата доступа: 20.01.2021.

11. Серафим [Медведев], о[теи]. Об автокефалии в Украине, и работе на КГБ иерархов МП // Христианская Церковь [Электронный ресурс]. - 2021. Режим доступа: https://www.paraklit.org/fragment18/ob-avtokefalii-v-ukraine-irabote-na-kgb-ierarhov-mp - Дата доступа: 20.01.2021.

12. Серафим [Медведев], о[теи]. Слепые вожди МП, апостольская преемственность. В какую церковь ходить? // Христианская Церковь [Электронный ресурс]. - 2021. - Режим доступа: https://www.paraklit.org/ fragment19/slepye-vozhdi-mp-apostolskaja-preemstvennost - Дата доступа: 20.01.2021.

13. Серафим [Медведев], о[теи]. Христианская Церковь. Наша вера и положение // Христианская Церковь [Электронный ресурс]. - 2021. - Режим доступа: https://www.paraklit.org/vera/osnovy - Дата доступа: 20.01.2021.

14. Слесарев А.В. Старостильный раскол в истории Православной Церкви (1924-2008). - М.: ОЛЦИ, 2009.

() П.В. Бочков, 2021. 